\title{
Rare Biogeochemical Phenomenon Associated to Manganese Patinas on Mural Painting and Granite Ashlars
}

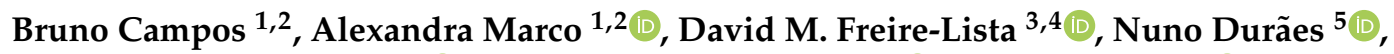 \\ Joaquin Silvestre-Albero ${ }^{6} \mathbb{D}$, Eduardo Ferreira da Silva ${ }^{5} \mathbb{D}^{(}$, Eduarda Vieira ${ }^{1}{ }^{\mathbb{D}}$, Manuela Pintado ${ }^{2}$ and \\ Patrícia R. Moreira $1,2, *$ (1)
}

1 CITAR Research Centre for Science and Technology of the Arts, Universidade Católica Portuguesa, R. de Diogo Botelho 1327, 4169-005 Porto, Portugal; bcampos@porto.ucp.pt (B.C.); alexandra.marco.ma@gmail.com (A.M.); evieira@porto.ucp.pt (E.V.)

2 CBQF Centre for Biotechnology and Fine Chemistry, Universidade Católica Portuguesa, R. de Diogo Botelho 1327, 4169-005 Porto, Portugal; mpintado@porto.ucp.pt

3 Department of Geology, UTAD Universidade de Trás-os-Montes e Alto Douro. Quinta de Prados, 5001-801 Vila Real, Portugal; davidfreire@utad.pt

4 CGeo Centro de Geociências da Universidade de Coimbra, Universidade de Coimbra—Polo II, Rua Silvino Lima, 3030-790 Coimbra, Portugal

5 GEOBIOTEC Research Centre, Department of Geosciences, University of Aveiro, Campus Universitário de Santiago, 3810-193 Aveiro, Portugal; nunoduraes@ua.pt (N.D.); eafsilva@ua.pt (E.F.d.S.)

6 Departamento de Química Inorgánica, UA Universidad de Alicante, Carretera de San Vicente del Raspeig s/n, 03690 San Vicente del Raspeig, Spain; joaquin.silvestre@ua.es

* Correspondence: prmoreira@ucp.pt

Citation: Campos, B.; Marco, A.; Freire-Lista, D.M..; Durães, N.;

Silvestre-Albero, J.; da Silva, E.F.;

Vieira, E.; Pintado, M.; Moreira, P.R. Rare Biogeochemical Phenomenon Associated to Manganese Patinas on Mural Painting and Granite Ashlars. Coatings 2021, 11, 917. https:// doi.org/10.3390/coatings11080917

Academic Editor: Maurizio Licchelli

Received: 21 June 2021

Accepted: 27 July 2021

Published: 30 July 2021

Publisher's Note: MDPI stays neutral with regard to jurisdictional claims in published maps and institutional affiliations.

Copyright: (c) 2021 by the authors. Licensee MDPI, Basel, Switzerland. This article is an open access article distributed under the terms and conditions of the Creative Commons Attribution (CC BY) license (https:// creativecommons.org/licenses/by/ $4.0 /)$.
Abstract: This article discloses a rare and outstanding type of Mn-rich black-blue patina found on mural painting and granite ashlars located in the church of Sta. Marinha, north of Portugal, and conjectures the phenomenon associated to the appearance of such patinas in different surface materials. This Mn-patina reported on mural painting and their origin is probably assigned to manganese leaching from building materials (i.e., granite and phyllites). Stained mural painting and granite examined by XPS and SEM have showed patinas enriched with manganese (IV) oxide, potentially catalysed by a microbiota, like fungi, observed in SEM micrographs. The pigments used to depict mural painting and groundwater were also analysed by micro-Raman and ICP-MS, respectively, indicating that they are unlikely manganese sources. Unstained building materials, such as granite ashlars, historic joints, mortars and phyllite rocks, were also analysed by ICP-MS showing that historic joints and mortars present significant concentrations of manganese, possibly associated to their absorbing feature. The main materials with potential to impart manganese to Mn-rich patinas are granite ashlars and phyllites. The aim of this investigation is to reveal and ascertain the hypothetical sources and the phenomenon responsible for the Mn-rich black-blue patina appearance, both on mural painting and granite ashlars.

Keywords: manganese patina; weathering; stained mural painting; biogenic patina

\section{Introduction}

Cultural Heritage is frequently under threat and the phenomenon associated to its deterioration is mainly ascribed to anthropogenic actions, environmental influence and/or microbial colonisation. Monuments are highly susceptible to deterioration, triggered by environmental and anthropogenic conditions, such as high concentration of airborne particles and volatile organic compounds originated from combustion of carbonaceous materials, like fossil fuel and candles [1,2]. Air pollution is a factor that intensifies the deterioration of historic buildings and it can be observed by the presence of black crusts in carbonate (e.g., gypsum crusts) or in granitic stones, inducing superficial detachments [3]. 
Microbiological colonization may be responsible for the monuments physical and chemical degradation and for aesthetic changes [4], depending on water sources, adequate temperature, solar exposure, and atmospheric deposits [5]. The major groups responsible for this degradation are bacteria and fungi, coexisting simultaneously. They constitute the larger part of the biomass existent in stone monuments [6] forming biofilms [7]. These biofilms act as adhesive retaining particles, sooth, humidity, altering temperature and desfiguring the materials $[8,9]$. Biofilm patinas vary in morphology and colour, accordingly to the taxonomic group, and environmental conditions from rose to yellow, green, grey, brown and black [10].

Blackening of cultural heritage is a chromatic changing of materials, perceived as a thin superficial layer and might include a combination of systems related to the composition of materials, microbiome proliferation and surrounding environment. Nomenclature associated to the observed blackening pigmentation can have different expressions depending on the size, shape and brightness [11]. The most common terms found in literature are black crusts [12,13], patinas [14], films [15], stains [16], spots [17], nodes [18], pits [19] and discs [20].

The formation of blackening is commonly attributed to gypsum formation, a reaction between sulphur di/trioxide gases and calcium, that accumulates carbon particles, dust, ashes and other dark pollutants. The source of $\mathrm{Ca}$ in historic buildings can be found in joint mortars [21] and plagioclases when the building stone is a silicate rock (e.g., granites) [22] or from calcite/dolomite, when raw stone is a limestone or marble. Also, iron oxy-hydroxides and Fe-rich clay minerals can be found on heritage stones causing colour changes on its surface [23].

Chemical deterioration of some pigments used in murals might also cause a black discolouration [24], namely, red lead $\left(\mathrm{Pb}_{3} \mathrm{O}_{4}\right)$ [25], white lead $\left(\mathrm{Pb}_{3}\left(\mathrm{CO}_{3}\right)_{2}(\mathrm{OH})_{2}\right)$ [26], cinnabar (HgS) [27], azurite $\left(\mathrm{Cu}_{3}\left(\mathrm{CO}_{3}\right)_{2}(\mathrm{OH})_{2}\right)$ [20] and hematite $\left(\mathrm{Fe}_{2} \mathrm{O}_{3}\right)$ [28].

On the other hand, microbial activity can induce the emergence of biogenic black patinas such as melanin production by actinomycetes or microcolonial fungi and fungal/bacterial oxidation of iron and manganese [29]. Biodeterioration is associated to heterogeneous microbial species embedded in extracellular polymeric substances (EPS), forming a biofilm. The EPS matrix is a result of complex metabolic activities underlying the production of (in)organic acids, anionic exopolymers, amino acids and proteins [30]. These metabolites are even responsible for the diagenetic changes of minerals, causing detrimental effects, and influencing the occurrence of some chemical reactions such as acidolysis, alkaline hydrolysis, complexation and oxidoreductive corrosion processes, triggering biocorrosion of building materials and changes in the pigmentation of stone artefacts and painted artworks [23,31].

\section{Materials and Methods}

\subsection{Sampling}

The collection of samples is illustrated in Figure 1a and it is divided in eight sampling sites. M1 and M2 (represented by squares) are the sampling locations for mortars characterisation by thin sections of mural mortars from 15th and 16th centuries, respectively [32]. Black-blue patina samples were collected on both campaigns: one from the first (MP3) and five from the second (MP1, 2, 4-6) campaigns. The samples from MP1-3 sites were collected at the edge of the mural with dimensions of $3 \mathrm{~mm} \times 3 \mathrm{~mm} \times 3 \mathrm{~mm}(\mathrm{~L} \times \mathrm{W} \times \mathrm{H})$. The samples from MP4-6 sites were thoroughly collected at the surface of the patina by scrapping, gathering a maximum of $5 \mathrm{mg}$ per sample. The analysis of each sample was repeated three times, at least, and the values reported are the result of an average and respective standard deviation. 

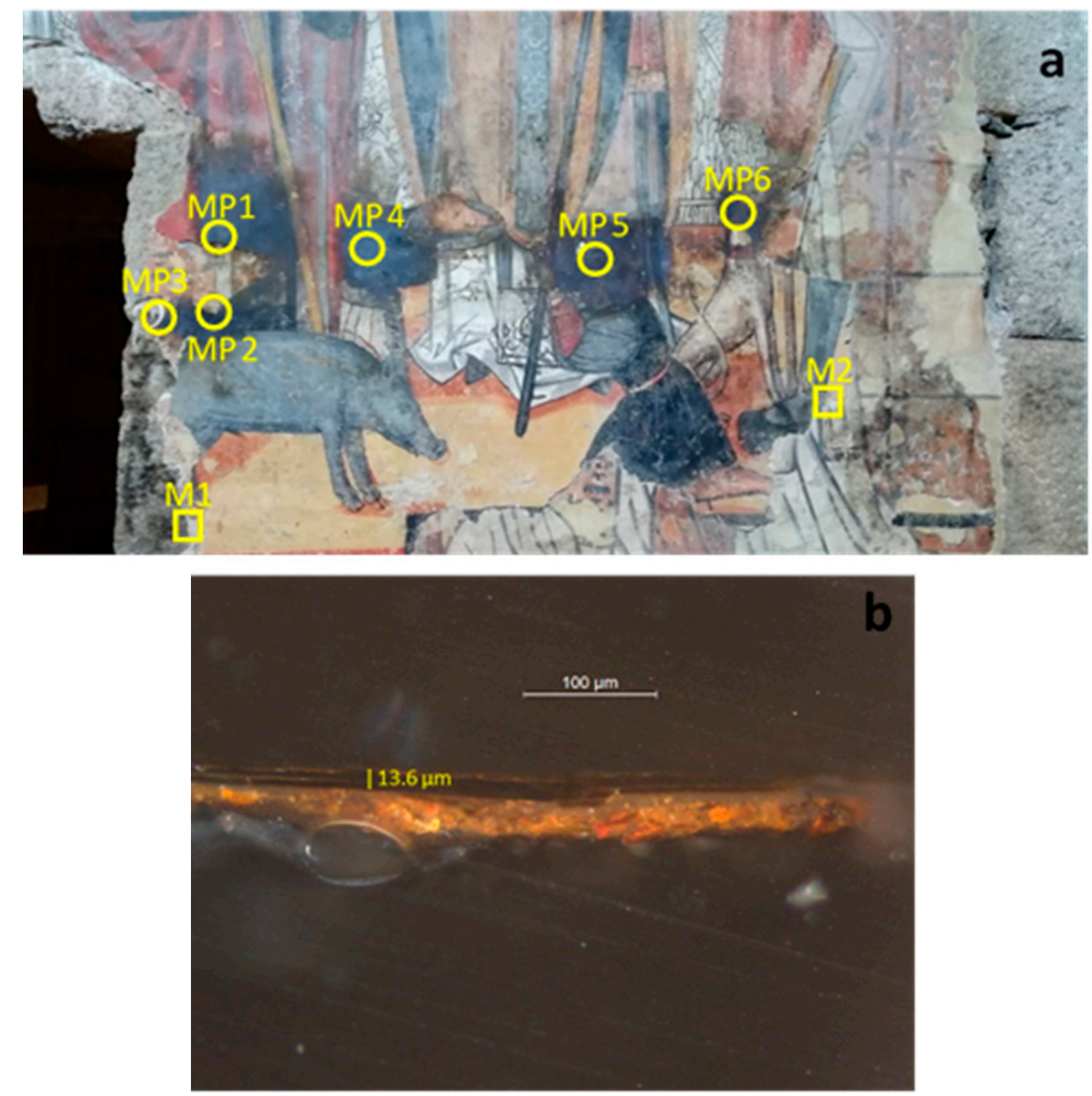

Figure 1. (a) Black-blue patina coating showing the sampling sites; (b) cross section of sample MP3 observed under standard optical microscope with visible light.

The report of black-blue colouration on mural painting do not have a specific date since its very beginning but local citizens claim that it has been growing until the size and extent of the actual patina. A cross section film collected at MP3 site where a black-blue patina occurs is shown in Figure 1b. As it can be observed, the patina formed on the mural surface is merely superficial (roughly 9-18 $\mu \mathrm{m}$ in depth from the mural surface) overlapping an orange pigment.

To formulate a hypothesis about the composition and the origin of the patina, optical, chemical and mineralogical analyses were carried out through optical microscopy, microRaman, X-Ray Diffraction (XRD), X-Ray Fluorescence (XRF), Scanning Electron Microscopy (SEM), X-ray Photoelectron Spectroscopy (XPS) and Inductively Coupled Plasma Mass Spectrometry (ICP-MS).

\subsection{Optical Microscopy}

A small amount of various micro-samples was embedded in epoxy resin and cut using a diamond blade. The cross-sections were first abraded with carbon papers (800-500 mesh) and then polished using diamond pastes $(6,3,1$ and $0.25 \mu \mathrm{m})$. The cross sections were observed under a Leitz Laborlux polarizing microscope (Leitz, Wetzlar, Germany) using visible and ultraviolet lamps.

\subsection{Micro-Raman Spectroscopy}

A Raman spectrometer HORIBA XPlora ${ }^{\mathrm{TM}}$ (Tokyo, Japan) equipped with a diode laser of $20 \mathrm{~mW}$ operating at $782 \mathrm{~nm}$, and coupled to an Olympus microscope (Tokyo, Japan), was used for the analysis of the mural painting micro-samples. Raman spectra were acquired in extended mode in the $100-2000 \mathrm{~cm}^{-1}$ region, with a diffraction granting of $600 \mathrm{~T}$, a hole 
of $300 \mu \mathrm{m}$ and a slit of $50 \mu \mathrm{m}$. The laser was focused with an Olympus 509 lens, $10 \%$ of the laser power on the sample surface (10 s of exposure, 10 cycles of accumulation).

\subsection{X-ray Diffraction (XRD)}

A fragment of each mortar (M1 and M2) was pulverised in an agate mortar to an approximate size of $50 \mu \mathrm{m}$ to conduct powder X-ray diffraction (XRD) for determining the principal mineralogical composition. For the XRD analysis a MiniFlex benchtop X-ray diffractometer (Rigaku, Tokyo, Japan) operated at $40 \mathrm{kV}$ and $30 \mathrm{~mA}$ using a copper anode $(\mathrm{CuK} \alpha$ radiation; $\lambda=1.5405 \AA)$ and a graphite monochromator.

The diffractograms were obtained over the $2 \theta^{\circ}$ range from $2^{\circ}$ to $68^{\circ}$, with a counting step of $0.02^{\circ} / \mathrm{s}$ in continuous mode and processed with a Miniflex Guiadance and PDXL 2 Rigaku Diffraction software (version 2, Rigaku Corporation, The Woodlands, TX, USA).

\subsection{X-ray Fluorescence (XRF)}

The elemental analyses of the patina were performed in situ using a portable X-ray fluorescence ( $\mathrm{pXRF}$ ) device conducted with a Thermo Scientific Niton XL3t-900 GOLDD (Geometrically Optimized large Drift Detector) analyzer (Waltham, MA, USA) equipped with a silver $(\mathrm{Ag})$ target and a $25 \mathrm{~mm}^{2}$ Silicon Drift Detector (SDD) with a resolution of $145 \mathrm{eV}$. The areas of interest were pinpointed using the integrated colour CCD camera and the integrated $3 \mathrm{~mm}$ small-spot collimation. All pXRF analyses were measured in triplicate using the mining mode with a total time of analysis settled at $180 \mathrm{~s}$, putting the pXRF nozzle directly on the surface of the patina.

\subsection{Scanning Electron Microscopy (SEM)}

SEM was used to obtain the samples topographic information using large magnifications. For the preservation of biological structures, the samples were sputtered with gold on a Polaron Sputter Coater (Quorum, Houston, TX, USA). The examination was performed on the Jeol JSM-5600LV (Tokyo, Japan) scanning electron microscope.

\subsection{X-ray Photoelectron Spectroscopy (XPS)}

The spectra were recorded using a Physical Electronics PHI 5701 spectrometer (Chanhassen, MN, USA) with a non-monochromatic $\mathrm{Al} \mathrm{K} \alpha$ radiation $(300 \mathrm{~W}, 15 \mathrm{kV}, h v=1486.6 \mathrm{eV})$ as the excitation source. Spectra were recorded at $45^{\circ}$ take-off angle by a concentric hemispherical analyser operating in the constant pass energy mode at $25.9 \mathrm{eV}$, using a $720 \mathrm{~mm}$ diameter analysis area. Under these conditions the $\mathrm{Au} 4 f_{7 / 2}$ line was recorded with $1.16 \mathrm{eV}$ FWHM at a binding energy of $84.0 \mathrm{eV}$. The spectrometer energy scale was calibrated using $\mathrm{Cu} 2 p_{3 / 2}, \mathrm{Ag} 3 d_{5 / 2}$ and $\mathrm{Au} 4 f_{7 / 2}$ photoelectron lines at $932.7,368.3$ and $84.0 \mathrm{eV}$, respectively. Charge referencing was done against adventitious carbon (C 1s $284.8 \mathrm{eV}$ ). Samples were mounted on a sample holder with adhesive tape and kept overnight in high vacuum in the preparation chamber before being transferred to the analysis chamber of the spectrometer. Each region was scanned with several sweeps until a good signal to noise ratio was observed. The pressure in the analysis chamber was maintained lower than $10^{-9}$ Torr. A PHI ACCESS ESCA-V6.0 F software package was used for acquisition and data analysis. A Shirley-type background was subtracted from the signals. Recorded spectra were always fitted using Gauss-Lorentz curves in order to determine more accurately the binding energy of the different element core levels. The accuracy of binding energy (BE's) values was within $\pm 0.1 \mathrm{eV}$.

\subsection{Inductively Coupled Plasma Mass Spectrometry (ICP-MS)}

To understand if groundwater can be a source of the constituent elements of the patina either on granite ashlars or on mural painting, a chemical analysis of a groundwater sample collected in a spring near the church was analysed. The water sample $(50 \mathrm{~mL})$ was filtered on site through a $0.45 \mu \mathrm{m}$ nitrocellulose filter and acidified with $0.5 \mathrm{~mL}$ of $\mathrm{HNO}_{3}$. In addition, several samples of the wall's rocks (granite and phyllites, the latter used in some joints between granite blocks), mortar samples and mural painting were collected (Figure S1 and Table S1 in Supplementary Materials) and submitted to an acid digestion 
$\left(3: 1 ; \mathrm{HNO}_{3}: \mathrm{HCl}\right)$ on a heating plate to pass the constituents in solution. Both water and solid samples were analysed by inductively coupled plasma mass spectrometry (ICP-MS) using a spectrometer from Agilent Technologies (Santa Clara, CA, USA, model 7700 series).

\section{Results}

\subsection{Identification of Pigments Used in Mural Painting by Micro-Raman}

The micro-Raman assignments of the pigments gathered from the two mural painting campaigns in Sta. Marinha church nave are displayed in Table S2. The band position allowed to identify the pigments from both campaigns and its ground layers.

The colour palette is, as normal in mural painting, somewhat reduced, composed of white, brown, grey, black, and different shades of yellow, orange, and red. At the moment, neither the yellow nor the brown pigments were tested by micro-Raman, although the information collected from pXRD allowed their identification as iron oxides.

The white pigments from the first and second campaign display calcite $\left(\mathrm{CaCO}_{3}\right)$ at $1088 \mathrm{~cm}^{-1}$ and cerussite, basic lead (II) $\left(\mathrm{PbCO}_{3}\right)$ at very strong bands of 1055 and $1051 \mathrm{~cm}^{-1}$, respectively, and comprise not only the decoration but also the ground layer, showing the existence of just one fine mortar layer.

The orange pigments from both campaigns are iron (III) oxides $\left(\mathrm{Fe}_{2} \mathrm{O}_{3}\right)$ containing hematite, identified due to the intense Raman peaks at 224, 295, 355 and $410 \mathrm{~cm}^{-1}$ on the first campaign and 232, 289, 406, 604 and $1301 \mathrm{~cm}^{-1}$ on the second campaign, while the latter also displays a medium intensity band at $1054 \mathrm{~cm}^{-1}$ of white lead (i.e., cerussite).

The red pigment from the first campaign is cinnabar, mercury (II) sulfide (HgS), a valuable pigment with a very strong band at $253 \mathrm{~cm}^{-1}$, a weak band at $283 \mathrm{~cm}^{-1}$, and a medium band at $346 \mathrm{~cm}^{-1}$. The red from the second campaign is an iron (III) oxide with very strong bands at 231 and $286 \mathrm{~cm}^{-1}$ and a medium band at $405 \mathrm{~cm}^{-1}$ and with the presence of calcite at $1088 \mathrm{~cm}^{-1}$.

The grey pigment from the second campaign is a mixture of calcite (peak at $1092 \mathrm{~cm}^{-1}$ ) and carbon black (amorphous carbon, with three broad Raman bands at 1330, 1586 and $1619 \mathrm{~cm}^{-1}$ ). The black pigments are carbon-based displaying bands at 1331 and $1613 \mathrm{~cm}^{-1}$ on the first and 1328 and $1591 \mathrm{~cm}^{-1}$ on the second campaign.

\subsection{Mineralogical Characterisation of Mortars by XRD}

The mineralogical composition of the two mortars is similar, both showing mainly quartz and calcite (Figure 2). XRD of M1 presents minerals associated to granite such as potassium feldspar, biotite and anorthite, which are possibly derived from the granite that outcrops around Sta. Marinha Church. This mortar sample also shows portlandite, which indicates that it has not been fully carbonated. This fact can be explained due to the existence of the two layers observed with petrographic microscopy and the rapid coating of the lower layer, preventing its carbonation.

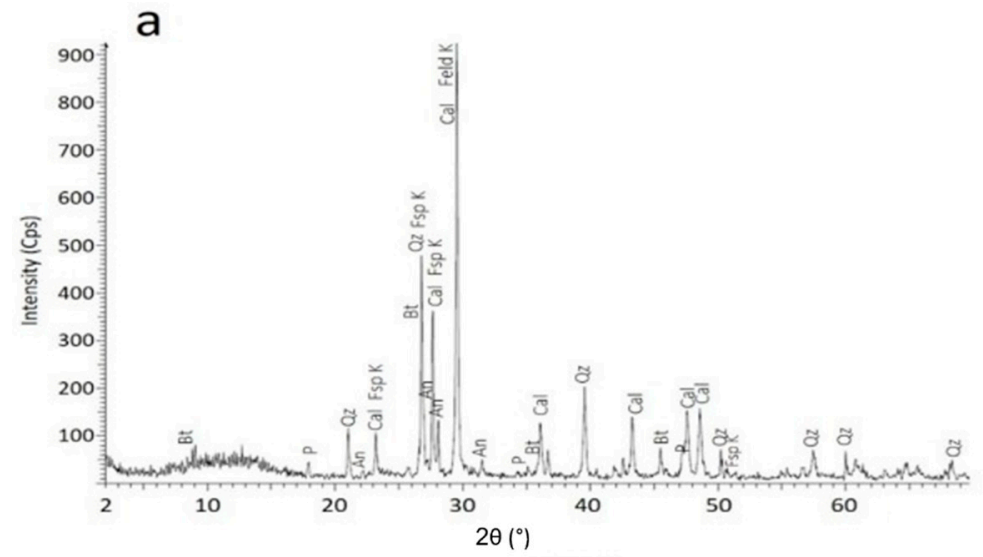

Figure 2. Cont. 


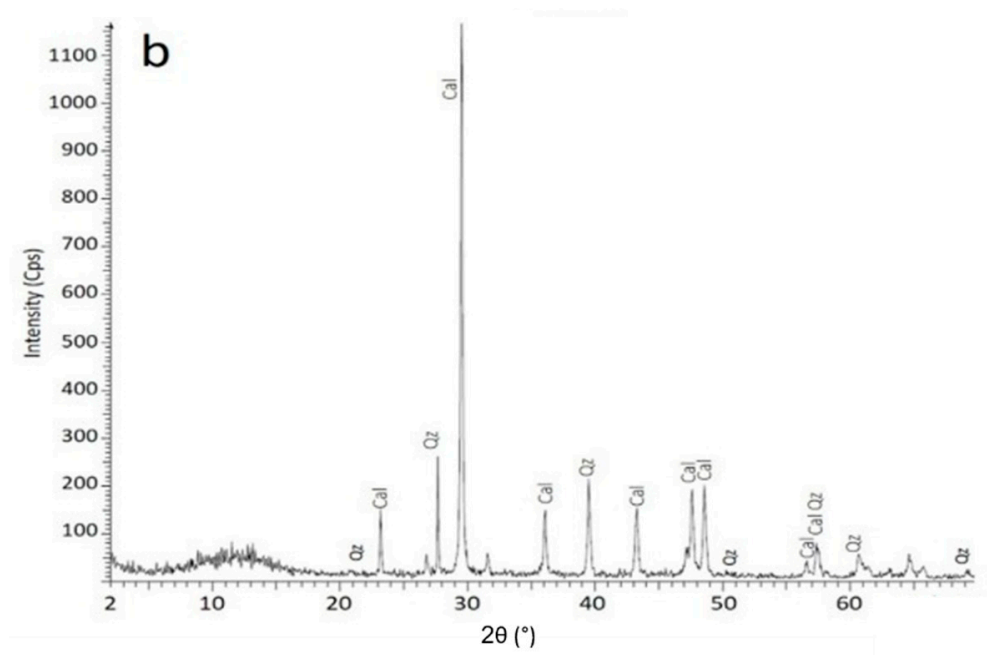

Figure 2. XRD patterns acquired for the mortar specimens (a) M1 and (b) M2. An: anorthite. Bt: biotite. Cal: calcite. Fsp K: Potassium feldspar. Qz: quartz. P: portlandite.

\subsection{Identification and Chemical Composition of Black-Blue Stains on Mural Painting and Granite Ashlars}

3.3.1. In situ Elemental Analysis by XRF

Concerning XRF analysis made on stained granite, Fe and Mn are the elements common to black-blue stains and the results are $0.73 \%$ and $2.12 \%$, respectively. The weight percentage of Fe is lower in stained granite than in the raw sample (less 0.72 times), while the opposite is verified for Mn with an increase of 27 times, approximately (Figure S2 and Table S3).

Regarding stained mural painting, the results revealed the presence of some typical inorganic elements, such as $\mathrm{Al}, \mathrm{Ca}, \mathrm{K}$ and $\mathrm{Si}$, as well as manganese $(1.71 \% \pm 0.36 \%)$ and iron $(1.17 \% \pm 0.53 \%$ ) (Table S4). Comparing this result with stained granite, the percentage of Fe rises to $62 \%$ and $\mathrm{Mn}$ decreases $24 \%$. Notwithstanding, Mn/Fe ratio in stained mural is 1.47 and 3.18 for stained granite. These data indicate an influence of Mn over Fe, being attributed to $\mathrm{Mn}$ the black-blue patina on mural painting and granite surface.

\subsubsection{Oxidation State of Mn by XPS}

The samples from MP1-3 sites were collected at the mural edge and examined by XPS (Figures S3a and S4). The assignments of calcite for MP3 sample can be observed at 531.45 (O 1s) and $289.62 \mathrm{eV}$ (C 1s) (Figure S3c,d) and confirmed by the spin-dublet of Ca $2 p$ region at $347.28\left(\mathrm{Ca} 2 p_{1 / 2}\right)$ and $350.68 \mathrm{eV}\left(\mathrm{Ca} 2 p_{3 / 2}\right)$ (Figure S3b). The chemical shift between $\mathrm{Ca} 2 p_{1 / 2}$ and $\mathrm{Ca} 2 p_{3 / 2}$ core level is $3.4 \mathrm{eV}$, furthermore, the intensity ratio of both peaks is approximately 2:1, respectively, being compatible with $\mathrm{CaCO}_{3}$ [33].

The presence of silica $\left(\mathrm{SiO}_{2}\right)$ at $102.35 \mathrm{eV}(\mathrm{Si} 2 p 3)$ and silicates $(\mathrm{Si}-\mathrm{O})$ at $532.81 \mathrm{eV}$ (O 1s) are also proven (Figure S3d,f). Frequently, it is found in mortars obtained from limestone a considerable amount of silica and alumina $\left(\mathrm{Al}_{2} \mathrm{O}_{3}\right)$ that, in this case, is detected at $74.17 \mathrm{eV}$ (Al 2p3) (Figure S3g). The presence of nitrogen and carbon is also shown at 407.26 (N 1s) and $284.55 \mathrm{eV}$ (C 1s) corresponding to nitrates and adventitious carbon, respectively (Figure S3c,e). The evaporation/precipitation cycles caused either by sodium chlorinated type groundwater that moves by capillarity in the stones, or by marine aerosols that reach these areas and are deposited on stone surface and mural materials usually in the form of salt efflorescence perceived as sodium chloride (halite) at $1071.69 \mathrm{eV}$ (Na 1s) (Figure S3h). These salts, lead to a lack of cohesion and adhesion of the strata, resulting in disintegrated and pulverulent layers [34,35].

The evidence of Mn patina is also observed at 641.84 and $644.72 \mathrm{eV}$ that are assigned to different oxidation states of manganese, namely, $\mathrm{Mn}(\mathrm{II} / \mathrm{III})$ (e.g., $\mathrm{Mn}_{3} \mathrm{O}_{4}$ ) and $\mathrm{Mn}$ (IV) (e.g., $\mathrm{MnO}_{2}$ ), respectively (Figure 3a). The same for iron at 712.28 and $714.90 \mathrm{eV}$ ascribed to 
$\mathrm{Fe}$ (II/III) (e.g., $\mathrm{Fe}_{3} \mathrm{O}_{4}$ ) and $\mathrm{Fe}$ (III) (e.g., $\mathrm{Fe}_{2} \mathrm{O}_{3}$ ), respectively (Figure 3b). The interpretation of MP1 and MP2 results are similar to the above statements (Table S5).

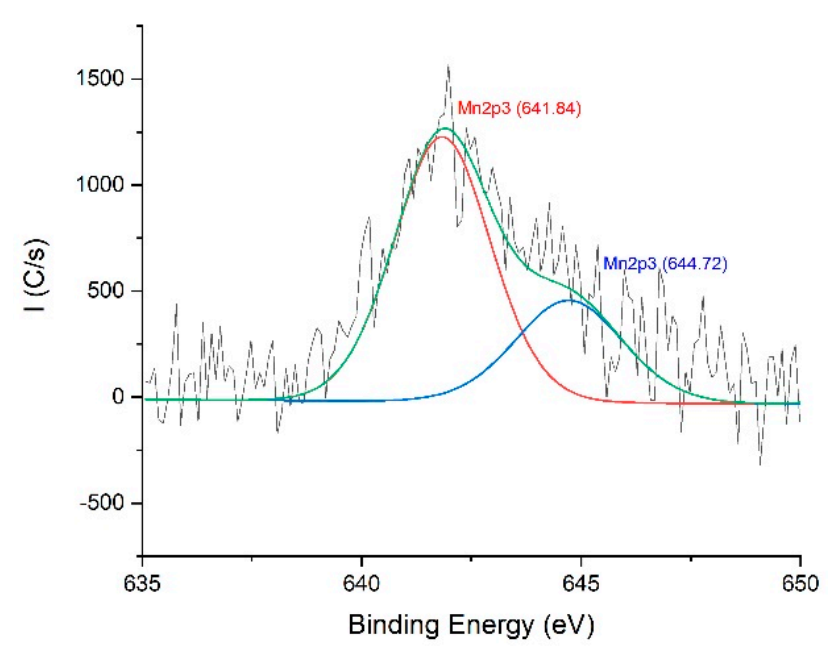

(a)

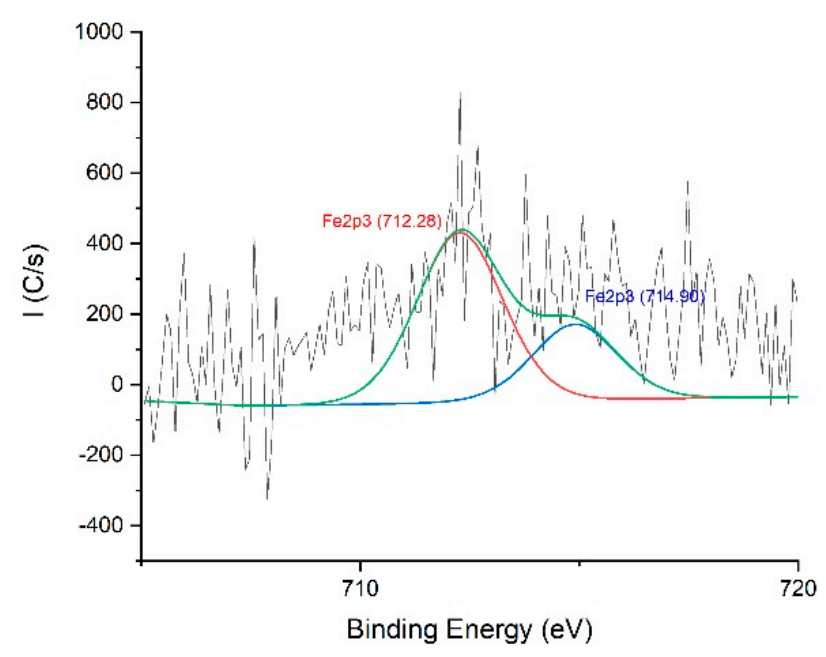

(b)

Figure 3. High resolution spectra of (a) Mn 2p3 and (b) Fe $2 p 3$.

\subsection{Surveying Mn Sources by ICP-MS}

The chemical analysis of groundwater, by ICP-MS, collected closer to the studied church are presented in Table S6. As can be observed, the groundwater showed low mineralization and the concentrations of $\mathrm{Fe}$ and $\mathrm{Mn}$, in particular, are very low, which excludes the water as the primary source of the main constituents of the black-blue patinas on granite and on mural painting.

The amount of Fe is considerable higher in phyllites (X1 and X2) than in granites (GR1 and GR2) and mortars (Arg1 and Arg2), while for Mn these differences are not so evident, with a sample of a mortar (Arg2) showing one of the highest contents of manganese (Table 1). In general, all these materials can be sources of Fe and $\mathrm{Mn}$ to form the black-blue patina. Although granite could be expected to be the major source of these elements given its much wider application as a building material in the church.

Table 1. Concentrations of major and trace elements of church building materials, namely unaltered rocks (granite and phyllites), joints and mortars.

\begin{tabular}{|c|c|c|c|c|c|c|c|c|c|}
\hline Element & Unit & GR1 & GR2 & $X 1$ & $X 2$ & J1 & J2 & Arg1 & Arg2 \\
\hline $\mathrm{Al}$ & \multirow{18}{*}{$\mathrm{mg} \cdot \mathrm{kg}^{-1}$} & 3537 & 9353 & 32,146 & 50,488 & 45,229 & 34,819 & 4295 & 8517 \\
\hline As & & 19.24 & 4.76 & 41.62 & 35.17 & 37.08 & 43.39 & 11.01 & 9.91 \\
\hline $\mathrm{Ba}$ & & 26 & 13 & 129 & 118 & 163 & 77 & 40 & 89 \\
\hline $\mathrm{Ca}$ & & 1175 & 2400 & 1103 & 12,136 & 5131 & 8711 & 231,486 & 195,166 \\
\hline K & & 1119 & 2049 & 13,307 & 7547 & 13,566 & 14,015 & 3501 & 6278 \\
\hline Co & & 0.58 & 1.37 & 8.62 & 12.87 & 126.46 & 28.46 & 3.85 & 5.02 \\
\hline $\mathrm{Cr}$ & & 7.23 & 5.01 & 70.65 & 33.68 & 59.37 & 55.13 & 10.44 & 15.02 \\
\hline $\mathrm{Cu}$ & & 10.17 & 3.38 & 31.46 & 15.20 & 23.12 & 27.05 & 94.54 & 13.60 \\
\hline $\mathrm{Fe}$ & & 3522 & 9874 & 48,730 & 35,833 & 30,674 & 32,733 & 4449 & 7945 \\
\hline $\mathrm{Mg}$ & & 343 & 1140 & 18,186 & 2703 & 10,705 & 10,646 & 2987 & 4868 \\
\hline $\mathrm{Mn}$ & & 39 & 141 & 427 & 203 & 1347 & 379 & 149 & 1068 \\
\hline $\mathrm{Na}$ & & 203 & 199 & 181 & 836 & 603 & 3370 & 1552 & 2140 \\
\hline $\mathrm{Ni}$ & & 3.10 & 3.48 & 35.97 & 17.74 & 42.00 & 24.87 & 10.82 & 14.66 \\
\hline $\mathrm{P}$ & & 504 & 1187 & 429 & 2480 & 700 & 542 & 240 & 528 \\
\hline $\mathrm{Pb}$ & & 15.9 & 8.5 & 8.4 & 11.7 & 29.0 & 8.0 & 270.5 & 70.7 \\
\hline $\mathrm{Sr}$ & & 8.0 & 5.3 & 13.3 & 29.9 & 18.4 & 31.1 & 217.3 & 1005.4 \\
\hline $\mathrm{U}$ & & 6.05 & 10.12 & 1.15 & 1.91 & 2.93 & 5.83 & 0.89 & 2.26 \\
\hline $\mathrm{Zn}$ & & 32.62 & 95.31 & 101.38 & 67.98 & 705.87 & 122.34 & 40.93 & 37.82 \\
\hline
\end{tabular}


In Table S7 the concentrations of the same element batch for granite and mural painting samples with evidence of black-blue patina, are displayed. In average, and with exception of As and $U$, the remaining elements analysed presented an enrichment of stained granite samples (G2 and G3) as high as 1.2 to 70 times regarding the raw granitic samples (GR1 and GR2), indicating secondary precipitation of those.

On the other hand, black-blue patina samples collected on the mural painting (MP1, MP4 and MP6) show, in average, higher contents of $\mathrm{As}, \mathrm{Ba}, \mathrm{Ca}, \mathrm{Cu}, \mathrm{Mn}, \mathrm{Na}, \mathrm{Ni}, \mathrm{Pb}$ and Sr than the black-blue patina of granite samples (G2 and G3), while the inverse occurs for the remaining elements analysed. Particularly evident are the high amounts of $\mathrm{Pb}, \mathrm{Cu}$, Ca and Sr (118, 13, 41 and 21 times higher than of black-blue patinas of granite samples, respectively), which is caused by the inputs of the materials used in the mural painting (e.g., $\mathrm{Pb}$-oxides and $\mathrm{Cu} / \mathrm{Pb}$-carbonates), as described previously.

Therefore, significant differences in the contents of several elements between the blackblue patinas formed over the granitic surface and mural painting indicates the prevailing of Fe precipitated on the granite surface, while a more complex mixing metal type, dominated by $\mathrm{Mn}$ and $\mathrm{Pb}$, can be ascribed for black-blue patinas on mural painting.

\subsection{Microbiological Evidence by SEM and SEM-EDX}

Manganese is the fifth most abundant transition metal on Earth and the second most common trace metal after iron [36], and manganese oxides are ubiquitous in almost any habitat [36] ranging from desert rocks [37], soils [38,39], water sources [40-42], and microbiological activity is one possible mechanism for it [36]. Iron and manganese (along with other metal ions) are essential for microbial metabolism $[43,44]$. The precipitation of Mn oxide minerals is achieved by direct (enzymatic) or indirect (abiotic) microbiological activity $[45,46]$.

Various different organisms have been reported for their ability to catalyze the oxidation of Fe(II) and Mn(II) [7,44] including bacteria [47,48], fungi [49-51] and algae [52], and research on their underlying mechanisms such as enzymes and metabolites is in progress [46]. Among the bacteria able to oxidize iron and manganese are Thiobacillus ferrooxidans, Bacillus, Leptospirillum, Aureobasidium strains among others, and between the fungi are Alternaria, Cladosporium, Fusarium, Penicillium, and Pleospora strains [53], some of which are common in stone and mural painting degradation and potential intervenient in the mechanism formation of the resultant black-blue patina.

Manganese self-oxidation only occurs at a pH above 8 [50], and since the granite on which religious buildings are made of, and Portland-type cement used in joints substitution have an acidic $\mathrm{pH}$, it is probable that the Mn-oxidation reported in this study is of biological production. However further tests are needed to corroborate this hypothesys.

The use of SEM intended the visualization of the microbiota on granite and mural painting samples.

The micrographs obtained by SEM were useful to observe the potential presence of microorganisms, fungi in particular, marked by extensive hyphae in three-dimensional networks (Figure 4a), biofilms, disintegration of the layers (powdery-like) and microfissures. It is also perceived in one sample, a colony of coccoid-like cells (Figure $4 \mathrm{~b}$ ). Elemental maps were made of the mural painting samples with dark stains, evidencing the high content of manganese (Figure 5). At the moment, no identification of these species has been made. The species isolated by microbiology assays will be assessed for Fe and Mn oxidation ability. 


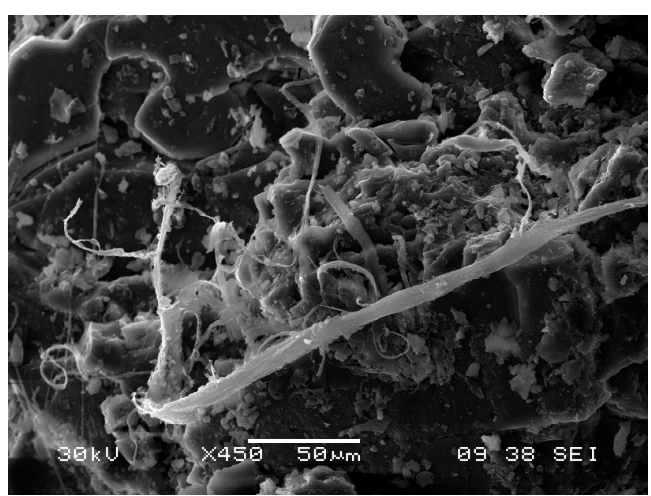

(a)

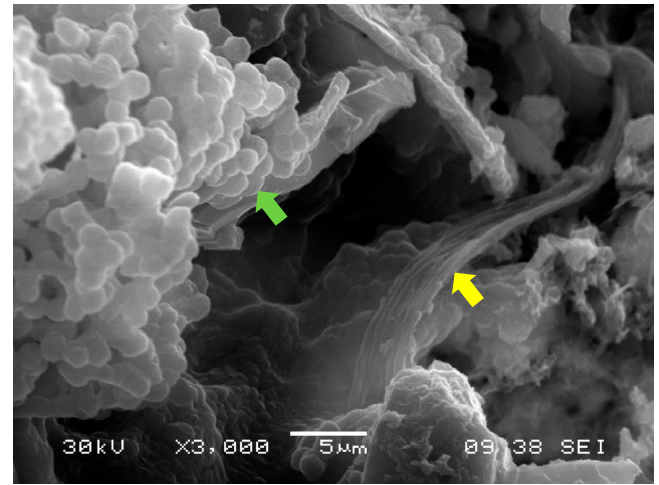

(b)

Figure 4. SEM micrographs of (a) a stained granite sample showing a network of hyphae and (b) a stained fresco sample evidencing a coccoid colony (green arrow) and hyphae (yellow arrow).

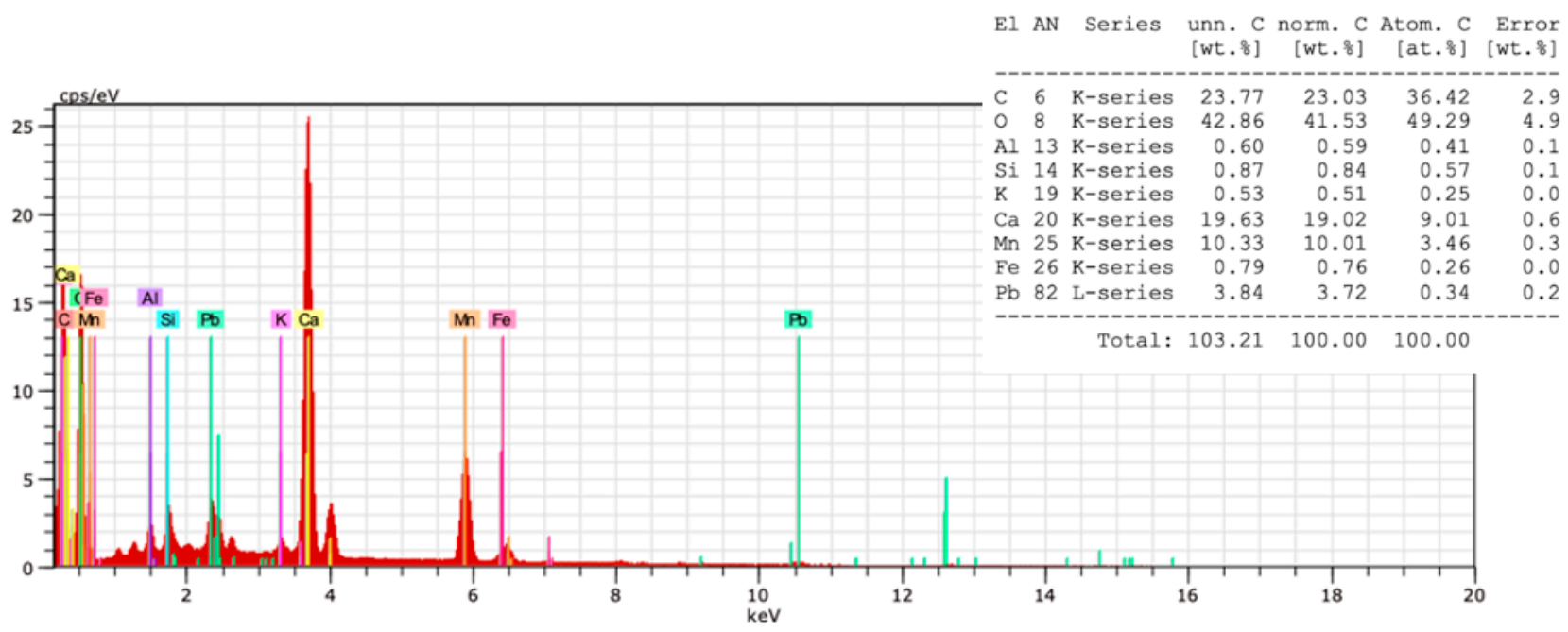

Figure 5. SEM-EDX of an elemental map of a mural painting sample with filamentous fungal hyphae.

\section{Discussion}

\subsection{Mn Leaching from Building Materials}

The survey of building materials such as joints (between granite blocks) and mortars, indicate an evident difference between the concentrations of manganese (by ICP-MS) in the same type of samples (J1/J2 = 3.55 and Arg2/ Arg1 = 7.17). Although this might suggest that both joint and mortar samples were possibly made with different raw materials or the soluble elements inside the building materials followed different leaching pathways from its inner until their surface, as can be proved by distinct concentrations of some elements such as $\mathrm{Al}, \mathrm{Ca}$, and $\mathrm{K}$ (by ICP-MS) in several building materials analysed. XRD showed the presence of some minerals in mortars, like potassium feldspar, biotite and anorthite that might be an evidence of granite weathering or the presence of granite powder in the mortar constitution, being a common practice of that period. Even the joints have a crucial function in the moisture mitigation of historic buildings because they were traditionally made by slaked lime, sand, water, and some traces of ash, proved by the concentrations of $\mathrm{Ca}$ and $\mathrm{K}$ (ICP-MS). These are responsible for the evaporation of water from building materials, avoiding the leaching of minerals and efflorescence formation at the granite surface [54]. Another prominent proof that supports this statement is the replacement of historic joints by cement, hindering water permeability, due to its reduced porosity, that might withdraw the joint functionality and contribute to the appearance of salts at the granite surface [55] and respective mural painting. Some granite ashlars are clearly stained on the edge between the cemented joint and the granite ashlars. Being an evidence that historic joints could, 
previously, have absorbed the soluble manganese and after the replacement of historic joint by cement, the remaining manganese was probably leached through the interface between the cemented joint and the granite ashlars. Rarely, the cements produced with limestones, might also provide some $\mathrm{Mn}$, due to the intersubstitution of $\mathrm{Mn}$ and $\mathrm{Ca}$ in calcite, nevertheless, the percentage of manganese oxide in ordinary Portland cements is practically vestigial $[56,57]$.

An interesting point revealed by ICP-MS analyses is the chemical composition of granite in the joints between blocks (J1 and J2), which show an increase, in average, of 1.5 to 79 times higher than the raw granite samples (GR1 and GR2), with exception of uranium (Table 1). This proves that water, despite not being a relevant source of these elements, promotes the weathering reactions of minerals and the precipitation of the elements leached as secondary phases, which occurs preferably in micro-cracks and joints where percolation of water is facilitated.

Even, XRF and ICP-MS results suggest that Mn enrichment over Fe on the surface of stained materials could also be explained by the relative mobility of each ion inside porous stones, which is based on chemical-physical properties of two systems, the immovable stone and a mobile water based ionic solution where, for instance, porosity, $\mathrm{pH}$, internal flow pressure, changing of temperature, chemical affinity/interaction, surface charge and ionic radius are accountable parameters. Gupta \& Rao (2001) [58] demonstrated that the order of mobility for some elements in weathered granite is $\mathrm{Na}>\mathrm{Ca}>\mathrm{K}>\mathrm{Mn}>\mathrm{Mg}>\mathrm{Si}>\mathrm{Fe}$ $>\mathrm{Al}>\mathrm{Ti}$, using the XRF technique to determine the variation in relative abundance of the major elements. Thus, manganese has a natural tendency to migrate faster than iron. The slightly difference that imparts changings in the mobility of $\mathrm{Mn}^{2+}$ and $\mathrm{Fe}^{2+}$ can be supported by Pourbaix diagrams showing that manganese $\left(\mathrm{Mn}^{2+}\right)[59]$ presents an Eh-pH area for its soluble state higher than iron $\left(\mathrm{Fe}^{2+}\right)[60]$ and the $\mathrm{pH}$ range values that iron can be soluble is smaller than that of manganese (c.a. until 7.0 and 7.5, respectively), suggesting that manganese (II) migration tends to be more facilitated than iron (II).

\subsection{Hypothetical Mechanism Formation of Mn-Rich Patina}

The phenomenon addressed in this article has found no similarity in bibliography, relatively to mural painting and historic granite buildings stained with manganese patinas. Recently, the presence of black manganese-rich coatings on historic buildings has been reported (Table S8) but its formation is still unclear.

The previous analytical results indicate a strong influence of weathering on building materials, as well as the possible influence of some microorganisms in the staining of granite and mural painting.

Traditional joints are responsible for the evaporation of water from building materials, avoiding the leaching of minerals and efflorescence formation at the granite surface [54]. According to previous arguments, joints and mortars can be excluded as the primary responsible for the manganese patina sourcing because they can act mainly as absorber materials of soluble manganese. Micro-Raman results showed that pigments based on manganese minerals were not used. Thus, phyllites and granite might be considered as possible source materials of manganese. Regarding phyllites, they were typically used in joints to fulfil some gaps between the granite ashlars, whenever was possible and necessary. The concentration of manganese in two phyllite samples ranged from 203 to $427 \mathrm{mg} \cdot \mathrm{kg}^{-1}$ and for granite from 39 to $141 \mathrm{mg} \cdot \mathrm{kg}^{-1}$. Apparently, both seems not to be significant. However, the decayed state of materials where the concentration of some elements is less than on the original ones must be considered. In fact, it is expected that granite could be the primary source material of manganese because the church is predominantly made of granite ashlars. Some evidences pointed out that granite rocks, even phyllites, from Vila Real region, with mountainous features, are the main geological materials responsible for the highest contents of manganese sediments registered along the River Corgo mainstream in the southward Vila Real and Vila Pouca de Aguiar valley, consequence of its draining down to the river, during a precipitation event [61]. This is indicative that higher concentrations of manganese could be found on historic granite quarry, where the granite rocks were 
collected. Finally, following the conclusions of previous articles represented in the Table S8, is expected that the appearance of black-blue manganese patinas on mural painting and granite might be influenced by biogenic oxidation of soluble manganese into insoluble $\mathrm{MnO}_{2}$. This evidence is supported by SEM images which indicate the presence of some microorganisms like fungi and bacteria.

\section{Conclusions}

The case of Vila Marinha church is a rare and outstanding manganese staining phenomenon due to the appearance of Mn-rich patinas on granite ashlars and on mural painting as well. A set of analytical techniques intending to realize the potential source of manganese and the formation of Mn-rich patinas were carried out. To unveil the source of $\mathrm{Mn}$, its concentration in groundwater was determined and the distribution of manganese in building materials such as pigments, joints, mortars, phyllites and granite ashlars was analysed. It was concluded that groundwater and pigments used in mural painting are unlikely sources of manganese due to its residual concentration. ICP-MS analysis showed some considerable concentrations of $\mathrm{Mn}$ in joints and mortars, but this kind of materials are expected to act mainly as absorbers rather than source materials. Finally, the phyllite and granite ashlars are the main candidates, contributing differently because phyllites contain an average concentration of $\mathrm{Mn}$ which is about 3.5 times higher than in granites, although the main building material of the church is the granite.

The formation of Mn-rich patinas seems to be associated to the water flow through the building materials, causing the leaching of manganese from its bearing minerals. At the surface of granite and mural painting, the soluble manganese was turned into insoluble $\mathrm{MnO}_{2}$, potentially catalysed by microorganisms, such as fungi, as can be observed in SEM images. The present article presents a general comprehension of a unique and complex staining phenomenon on granite and on mural painting.

Supplementary Materials: The following are available online at https: / www.mdpi.com/article / 10.3390/coatings11080917/s1, Figure S1: Sampling sites for ICP-MS analysis, Figure S2: In situ sampling sites of granite stains from (a) front wall and (b) back wall of mural painting, Figure S3: (a) XPS survey spectra of MP3; high resolution spectra of (b) Ca $2 p$ (c). C 1 s. (d) O 1s. (e) N $1 s$. (f) Si 2p3. (g) Al 2p3 and (h) Na 1s, Figure S4: XPS survey spectra of (a) MP1 and (b) MP2, Figure S5: (a) Exterior façade of Sta. Marinha Church, Vila Marim, Portugal; (b) North wall dec-orated with mural painting, Table S1: Description of samples collected from Sta. Marinha Church and submitted to chemical analysis, Table S2: Raman assignments of pigments used in the first and second campaign., Table S3: Iron and manganese percentage of black-blue patina on granite. G0 = raw granite (without stain); Avg = average, Table S4: Weight percentage of the elements present in black-blue patinas by pXRF (normalized values). Bal = stands for balance, it represents the light elements within the sample not excited by the analyser; only values above $0.10 \%$ are presented in this table, Table S5: Assignments attributed to XPS peaks for MP1 and MP2 samples, Table S6: Concentrations of major and trace elements in groundwater of Vila Marim, Table S7: Concentrations of major and trace elements of granite and frescoes affected by black-blue patina, Table S8: Similar Mn patinas found on built heritage and caves.

Author Contributions: Conceptualization, A.M. and D.M.F.-L.; Data curation, D.M.F.-L. and N.D.; Formal analysis, J.S.-A.; Funding acquisition, N.D., E.V., M.P. and P.R.M.; Investigation, B.C., A.M. and D.M.F.-L.; Methodology, B.C. and A.M.; Project administration, E.V. and P.R.M.; Software, J.S.-A.; Supervision, M.P. and P.R.M.; Validation, D.M.F.-L. and N.D.; Visualization, J.S.-A. and E.F.d.S.; Writing—original draft, B.C.; Writing—review \& editing, A.M., D.M.F.-L., N.D. and E.F.d.S. All authors have read and agreed to the published version of the manuscript.

Funding: We would like to thanks the financial support of the project BIO4MURAL-Biotechnology innovative solutions for the removal of pigmentation and preventive conservation of cultural and historically relevant mural painting was funded by FEDER through project reference POCI-01-0145FEDER-029157-Operational Competitiveness and Internationalization Program and by National Funds from FCT-Foundation for Science and Technology (PTDC/HAR-ARQ/29157/2017); Alexandra Marco PhD research was supported by Foundation for Science and Technology (FCT) through $\mathrm{POCH}-$ Operational Human Capital Program, co-participated by the Social European Fund (FSE) 
and MCTES National Fund (SFRH/BD/125596/2016); Dr. David M. Freire-Lista is supported by FCT through Stimulus of Scientific Employment, Individual Support 2017. CEECIND/03568/2017. HERCULES Laboratory-Évora University and E-RHIS.pt infra-structure for the access to the platforms PT-MOLAB and PT-FIXLAB; and scientific collaboration through the Strategic Projects CITAR (UID/EAT/0622/2016), CBQF (UID/Multi/50016/2013) and GEOBIOTEC (UID/GEO/04035/2020).

Institutional Review Board Statement: Not applicable.

Informed Consent Statement: Not applicable.

Data Availability Statement: The data presented in this study are available in [insert article or supplementary material here].

Acknowledgments: The authors are grateful to the Laboratory of Geotechnics and Construction Materials of ISEP, namely, to José Augusto Fernandes and Isilda Costa for their support in the use of pXRF.

Conflicts of Interest: The authors declare no conflict of interest.

\section{References}

1. Derudi, M.; Gelosa, S.; Sliepcevich, A.; Cattaneo, A.; Cavallo, D.; Rota, R.; Nano, G. Environments., emission of air pollutants from burning candles with different composition in indoor. Environ. Sci. Pollut. Res. 2013, 21, 4320-4330. [CrossRef]

2. Perez-Monserrat, M.E.; Varas-Muriel, J.M.; de Buergo, A.M.; Fort, R. Black layers of decay and color patterns on heritage limestone as markers of environmental change. Geosciences 2016, 6, 4. [CrossRef]

3. Pozo-Antonio, J.S.; Papanikolaou, A.; Philippidis, A.; Melessanaki, K.; Rivas, T.; Pouli, P. Cleaning of gypsum-rich black crusts on granite using a dual wavelength Q-Switched Nd:YAG laser. Constr. Build. Mater. 2019, 226, 721-733. [CrossRef]

4. Prieto, B.; Silva, B.; Aira, N.; Álvarez, L. Toward a definition of a bioreceptivity index for granitic rocks: Perception of the change in appearance of the rock. Int. Biodeterior. Biodegrad. 2006, 58, 150-154. [CrossRef]

5. Guillitte, O. Bioreceptivity: A new concept for building ecology studies. Sci. Total Environ. 1995, 167, 215-220. [CrossRef]

6. Crispim, C.A.; Gaylarde, C.C.; Gaylarde, P.M. Biofilms on church walls in Porto Alegre, RS, Brazil, with special attention to cyanobacteria. Int. Biodeterior. Biodegradation 2004, 54, 121-124. [CrossRef]

7. Dakal, T.; Cameotra, S. Microbially induced deterioration of architectural heritages: Routes and mechanisms involved. Environ. Sci. Eur. 2012, 24, 36. [CrossRef]

8. Gaylarde, L.H.G.; Morton, C.C. Deteriogenic biofilms on buildings and their control: A review. Biofouling 1999, 14, 59-74. [CrossRef]

9. Ortega-Morales, P.M.; Guezennec, O.; Hernández-Duque, J.; Gaylarde, G.; Gaylarde, C.C. Phototrophic biofilms on ancient mayan buildings in Yucatan, Mexico. Curr. Microbiol. 2000, 40, 81-85. [CrossRef]

10. Cappitelli, F.; Abbruscato, P.; Foladori, P.; Zanardini, E.; Ranalli, G.; Principi, P.; Villa, F.; Polo, A.; Sorlini, C. Detection and elimination of cyanobacteria from frescoes: The case of the St. Brizio Chapel (Orvieto Cathedral, Italy). Microb. Ecol. 2009, 57, 633-639. [CrossRef]

11. Wichert, J. Slate as Dimension Stone-Origin, Standards, Properties, Mining and Deposits, 1st ed.; Springer: Berlin/Heidelberg, Germany, 2020.

12. La Russa, M.F.; Fermo, P.; Comite, V.; Belfiore, C.M.; Barca, D.; Cerioni, A.; de Santis, M.; Barbagallo, L.F.; Ricca, M.; Ruffolo, S.A. The Oceanus statue of the Fontana di Trevi (Rome): The analysis of black crust as a tool to investigate the urban air pollution and its impact on the stone degradation. Sci. Total Environ. 2017, 593, 297-309. [CrossRef]

13. Gaylarde, C.; Baptista-Neto, J.A.; Tabasco-Novelo, C.; Ortega-Morales, O. Weathering of granitic gneiss: A geochemical and microbiological study in the polluted sub-tropical city of Rio de Janeiro. Sci. Total Environ. 2018, 644, 1641-1647. [CrossRef] [PubMed]

14. Municchia, A.C.; Bartoli, F.; Bernardini, S.; Caneva, G.; della Ventura, G.; Ricci, M.; Suy, B.; Sodo, A. Characterization of an unusual black patina on the Neang Khmau temple (archaeological Khmer area, Cambodia): A multidisciplinary approach. J. Raman Spectrosc. 2016, 47, 1467-1472. [CrossRef]

15. Ogawa, A.; Celikkol-Aydin, S.; Gaylarde, C.; Baptista-Neto, J.; Beech, I. Microbial communities on painted wet and dry external surfaces of a historic fortress in Niterói, Brazil. Int. Biodeterior. Biodegrad. 2017, 123, 164-173. [CrossRef]

16. Alonso, L.; Creuzé-des-Châtelliers, C.; Trabac, T.; Dubost, A.; Moënne-Loccoz, Y.; Pommier, T. Rock substrate rather than black stain alterations drives microbial community structure in the passage of Lascaux Cave. Microbiome 2018, 6, 216. [CrossRef] [PubMed]

17. Marvasi, M.; Donnarumma, F.; Frandi, A.; Mastromei, G.; Sterflinger, K.; Tiano, P.; Perito, B. Black microcolonial fungi as deteriogens of two famous marble statues in Florence, Italy. Int. Biodeterior. Biodegradation 2012, 68, 36-44. [CrossRef]

18. González-Gómez, W.S.; Quintana, P.; Gómez-Cornelio, S.; García-Solis, C.; Sierra-Fernandez, A.; Ortega-Morales, O.; De la Rosa-García, S.C. Calcium oxalates in biofilms on limestone walls of Maya buildings in Chichén Itzá, Mexico. Environ. Earth Sci. 2018, 77, 230. [CrossRef] 
19. Sert, K.; Sterflinger, H. A new Coniosporium species from historical marble monuments. Mycol. Prog. 2009, 9, 353-359. [CrossRef]

20. Abdel-Haliem, M.E.F.; Sakr, A.A.; Ali, M.F.; Ghaly, M.F.; Sohlenkamp, C. Characterization of Streptomyces isolates causing colour changes of mural paintings in ancient Egyptian tombs. Microbiol. Res. 2013, 168, 428-437. [CrossRef]

21. Mosquera, S.; Benítez, M.; Perry, D. Pore structure in mortars applied on restoration: Effect on properties relevant to decay of granite buildings. Cem. Concr. Res. 2002, 32, 1883-1888. [CrossRef]

22. Pozo-Antonio, J.S.; Pereira MF, C.; Rocha CS, A.; Puente, I.; Figueiredo, C. Comparative study of deterioration forms on nearby granitic bridges from an urban setting in the NW Iberian Peninsula. Geomorphology 2016, 274, 11-30. [CrossRef]

23. Sanmartín, B.; Sanjurjo-Sánchez, P.; Prieto, J. Covering layers on granite buildings of northwestern Iberian Peninsula: When observable characteristics and lab characterization do not match. Coatings 2020, 10, 137. [CrossRef]

24. Coccato, P.; Moens, A.; Vandenabeele, L. On the stability of mediaeval inorganic pigments: A literature review of the effect of climate, material selection, biological activity, analysis and conservation treatments. Herit. Sci. 2017, 5, 12. [CrossRef]

25. de Ferri, G.; Mazzini, L.; Vallotto, F.; Pojana, D. In situ non-invasive characterization of pigments and alteration products on the masonry altar of S. Maria ad Undas (Idro, Italy). Archaeol. Anthropol. Sci. 2019, 11, 609-625. [CrossRef]

26. Vagnini, C.; Vivani, M.; Viscuso, R.; Favazza, E.; Brunetti, M.; Sgamellotti, B.; Miliani, A. Investigation on the process of lead white blackening by Raman spectroscopy, XRD and other methods: Study of Cimabue's paintings in Assisi. Vib. Spectrosc. 2018, 98, 41-49. [CrossRef]

27. Cotte, M.; Susini, M.; Metrich, J.; Moscato, N.; Gratziu, A.; Bertagnini, C.; Pagano, A. Blackening of pompeian cinnabar paintings: X-ray microspectroscopy analysis. Anal. Chem. 2006, 78, 7484-7492. [CrossRef] [PubMed]

28. Costantini, J.; Lottici, I.; Bersani, P.; Pontiroli, D.; Casoli, D.; Castro, A.; Madariaga, K. Darkening of lead- and iron-based pigments on late Gothic Italian wall paintings: Energy dispersive X-ray fluorescence, $\mu$-Raman, and powder X-ray diffraction analyses for diagnosis: Presence of $\beta-\mathrm{PbO}_{2}$ (plattnerite) and $\alpha-\mathrm{PbO}_{2}$ (scrutinyite). J. Raman Spectrosc. 2020, 51, 680-692. [CrossRef]

29. Gaylarde, P.; Ortega-Morales, C.; Bartolo-Pérez, B. Biogenic black crusts on buildings in unpolluted environments. Curr. Microbiol. 2007, 54, 162-166. [CrossRef]

30. Mihajlovski, P.; Seyer, A.; Benamara, D.; Bousta, H.; di Martino, F. An overview of techniques for the characterization and quantification of microbial colonization on stone monuments. Ann. Microbiol. 2015, 65, 1243-1255. [CrossRef]

31. Lian BChen YZhu, L.; Yang, R. Effect of microbial weathering on carbonate rocks. Earth Sci. Front. 2008, 15, 90-99. [CrossRef]

32. Caetano, J. O Marão E As Oficinas De Pintura Mural Nos Séculos XV E XVI; Aparição: Lisbon, Portugal, 2001.

33. Sahoo, J.; Kausar, P.; Lee, F.; Han, J. Facile fabrication of silver nanoparticle embedded $\mathrm{CaCO}_{3}$ microspheres via microalgaetemplated $\mathrm{CO}_{2}$ biomineralization: Application in antimicrobial paint development. RSC Adv. 2014, 4, 32562-32569. [CrossRef]

34. Gulzar, S.; Burg, J.P. Preliminary investigation of late Mughal period wall paintings from historic monuments of Begumpura, Lahore. Front. Archit. Res. 2018, 7, 465-472. [CrossRef]

35. Ferrazza, P.; Valls, L.P.; Zamorano, M.C.; Barber, G.; Radvan, D.; Chelmus, R.; Ratoiu, A.; Ghervase, L.; Cortea, L.; Ortiz, I. Multidisciplinary approach applied to the diagnosis of the facade of the Arciprestal Church of Santa María de Morella (Castellón, Spain). Scanning 2019, 2019, 1-14. [CrossRef] [PubMed]

36. Sujith, P.P.; Bharathi, P.A.L. Manganese oxidation by bacteria: Biogeochemical aspects. Progress Mol. Subcell. Biol. 2011, 52, 49-76.

37. Santelli, C.M.; Webb, S.M.; Dohnalkova, A.C.; Hansel, C.M. Diversity of Mn oxides produced by Mn(II)-oxidizing fungi. Geochim. Cosmochim. Acta 2011, 75, 2762-2776. [CrossRef]

38. Grote, G.; Krumbein, W.E. Microbial precipitation of manganese by bacteria and fungi from desert rock and rock varnish Geomicrobiol. J. 1992, 10, 49-57. [CrossRef]

39. Cahyani, M.; Murase, V.R.; Ishibashi, J.; Asakawa, E.; Kimura, S. Phylogenetic positions of $\mathrm{Mn}^{2+}$-oxidizing bacteria and fungi isolated from Mn nodules in rice field subsoils. Biol. Fertil. Soils 2009, 45, 337-346. [CrossRef]

40. Yang, L.; Zhang, W.; Zhang, Z.; Chen, Z.; Liu, H.; Ali, J.; Liu, M.; Li, F. Population structure of manganese-oxidizing bacteria in stratified soils and properties of manganese oxide aggregates under manganese-complex medium enrichment. PLoS ONE 2013, 8, e73778. [CrossRef] [PubMed]

41. Cerrato, J.M.; Falkinham, J.O.; Dietrich, A.M.; Knocke, W.R.; McKinney, C.W.; Pruden, A. Manganese-oxidizing and -reducing microorganisms isolated from biofilms in chlorinated drinking water systems. Water Res. 2010, 44, 3935-3945. [CrossRef]

42. Piazza, N.; Casalini, A.C.; Pacini, L.; Sanguinetti, V.A.; Ottado, G.; Gottig, J. Environmental bacteria involved in Manganese(II) oxidation and removal from groundwater. Front. Microbiol. 2019, 10, 119. [CrossRef]

43. Martínez-Ruiz, E.B.; Cooper, M.; Fastner, J.; Szewzyk, U. Manganese-oxidizing bacteria isolated from natural and technical systems remove cylindrospermopsin. Chemosphere 2020, 238, 124625. [CrossRef] [PubMed]

44. Costa, O.Y.; Oguejiofor, C.; Zühlke, D.; Barreto, C.C.; Wünsche, C.; Riedel, K.; Kuramae, E.E. Impact of different trace elements on the growth and proteome of two strains of Granulicella, class 'Acidobacteriia'. Front. Microbiol. 2020, 11, 1227. [CrossRef] [PubMed]

45. Zhou, H.; Fu, C. Manganese-oxidizing microbes and biogenic manganese oxides: Characterization, Mn(II) oxidation mechanism and environmental relevance. Rev. Environ. Sci. Bio/Technol. 2020, 19, 489-507. [CrossRef]

46. Zeiner, C.A.; Purvine, S.O.; Zink, E.; Wu, S.; Paša-Tolić, L.; Chaput, D.L.; Santelli, C.M.; Hansel, C.M. Mechanisms of manganese (II) oxidation by filamentous ascomycete fungi vary with species and time as a function of secretome composition. Front. Microbiol. 2021, 12, 81. [CrossRef]

47. Nealson, K.H. The Manganese-Oxidizing Bacteria. In The Prokaryotes; Springer: New York, NY, USA, 2006. 
48. Greene, A.C.; Madgwick, J.C. Heterotrophic manganese-oxidizing bacteria from Groote Eylandt, Australia. Geomicrobiol. J. 1988, 6, 119-127. [CrossRef]

49. Takano, K.; Itoh, Y.; Ogino, T.; Kurosawa, K.; Sasaki, K. Phylogenetic analysis of manganese-oxidizing fungi isolated from manganese-rich aquatic environments in Hokkaido, Japan. Limnology 2006, 7, 219-223. [CrossRef]

50. de la Torre, M.A.; Gomez-Alarcon, G. Manganese and iron oxidation by fungi isolated from building stone. Microb. Ecol. 1994, 27, 177-188. [CrossRef]

51. Timonin, M.I.; Illman, W.I.; Hartgerink, T. Oxidation of manganous salts of manganese by soil fungi. Can. J. Microbiol. 1972, 18, 793-799. [CrossRef]

52. Gounot, A.-M. Microbial oxidation and reduction of manganese: Consequences in groundwater and applications. FEMS Microbiol. Rev. 1994, 14, 339-349. [CrossRef]

53. Sterflinger, K. Fungi as Geologic Agents. Geomicrobiol. J. 2000, 17, 97-124. [CrossRef]

54. O'Brien, P.F.; Bell, E.; Santamaria, S.P.; Boyland, P.; Cooper, T.P. Role of mortars in the decay of granite. Sci. Total Environ. 1995, 167, 103-110. [CrossRef]

55. Brás, A.; Valença, A.; Faria, P. Performance-based methods for masonry building rehabilitation using innovative leaching and hygrothermal risk analyses. Sustain. Cities Soc. 2017, 28, 321-331. [CrossRef]

56. Dromgoole, E.L.; Walter, L.M. Iron and manganese incorporation into calcite: Effects of growth kinetics, temperature and solution chemistry. Chem. Geol. 1990, 81, 311-336. [CrossRef]

57. Osinubi, K.J.; Yohanna, P.; Eberemu, A.O. Cement modification of tropical black clay using iron ore tailings as admixture. Transp. Geotech. 2015, 5, 35-49. [CrossRef]

58. Gupta, S.; Rao, A. Weathering indices and their applicability for crystalline rocks. Bull. Eng. Geol. Environ. 2001, 60, 201-221. [CrossRef]

59. Sun, G.; Kitchaev, W.; Kramer, D.; Ceder, D. Non-equilibrium crystallization pathways of manganese oxides in aqueous solution. Nat. Commun. 2019, 10, 573. [CrossRef]

60. Perry, J.; Gateman, S.; Stephens, S.; Lacasse, L.; Schulz, R.; Mauzeroll, R. Pourbaix diagrams as a simple route to first principles corrosion simulation. J. Electrochem. Soc. 2019, 166, C3186-C3192. [CrossRef]

61. Reis, A.; Parker, A.; Alencoão, A. Storage and origin of metals in active stream sediments from mountainous rivers: A case study in the River Douro basin (North Portugal). Appl. Geochem. 2014, 44, 69-79. [CrossRef] 